\section{Russian acoustics scientists defended on 'secrets' charges}

[Moscow] Dozens of prominent Russian scientists have written to the Federal Security Service in support of their colleagues Vladimir Borodin and Mikail Galaktionov, of the Institute of Acoustics in Moscow, who could be accused of passing state secrets to a foreign company. The scientists claim the information had already been published.

Security service officers searched the institute laboratory headed by Borodin and found scientific reports prepared for the US Lockheed Sanders Corporation that had not been authorized by the institute. Nikolai Dubrovsky, the institute's director, launched an inquiry that concluded that the reports should not have been passed to the company.

But Borodin, who was not invited to participate in the inquiry, says that details of his research on which the reports were based had been published in the institute's proceedings in 1995.

The Institute of Acoustics used to be one of the most prosperous research centres in Russia, generously financed by the military. But in 1994 it suddenly found itself on the verge of poverty. Borodin tried to save his department by entering a contest announced by Lockheed Sanders for Russian scientists. They were invited to collaborate in developing a system to protect oil derricks in shallow waters from damage by submarines.

Dubrovsky prohibited Borodin's lab from taking part in the contest, but Borodin and Galaktionov decided to enter as private individuals. They won the competition and started the research. Later, when they needed money for experiments but could not guarantee successful results, Lockheed terminated the contract.

Dubrovsky has not explained why the work is considered secret. But A. Luchinin, a specialist in hydro-acoustic protection systems who is not connected with the acoustics institute, told the inquiry that the work does not contain secrets. The same conclusion was reached at a seminar held by the Russian Academy of Sciences last year.

Borodin says: "The worst thing that could happen is that Galaktionov will leave science. He is now having to work for a commercial firm. Galaktionov's institute salary is $\mathbf{2 5 5}$ rubles (US\$42) a month, but he needs to pay for expensive medical treatment for his child, who underwent a complex operation in France when Galaktionov worked there."

The operation was done free of charge after his French colleagues appealed to the then President François Mitterrand. "But now Galaktionov is in Russia, where the authorities are concerned about keeping secrets, not people," says Borodin.

Carl Levitin

\title{
Fight hots up over Toronto racial discrimination claim
}

[MONTREAL] The University of Toronto is coming under renewed pressure to resolve a long-standing battle with a seismologist of Chinese descent who has accused the university of racial discrimination by repeatedly denying him a tenure-track professorship.

Kin-Yip Chun joined the university's physics department in 1985, and received no salary during almost 10 years of service, deriving his income entirely from external research contracts. During that time, however, he taught students, published 26 papers, and attracted more than C $\$ 1.4$ million (US\$1 million) in research grants.

Cecil Yip, former vice-dean of the medical faculty, was appointed by the university to investigate Chun's charges that he had been passed over for tenure. In 1994, Yip concluded that, although he could find no evidence of discrimination on the basis of race, Chun had been "exploited" by the physics department. Shortly afterwards, Chun was escorted off the university site by campus police, and banned from it for three years. No reason was given at the time.

The academic freedom and tenure committee of the Canadian Association of University Teachers (CAUT) has expressed concern about the university's failure to resolve the issue. The committee recently informed the university president, Robert Prichard, that it is preparing a report on the case.

Prichard has been invited to see the report before publication - which may be as early as next month - and to publish a commentary alongside it. At a meeting of the university's academic board last year, at which Chun's case was discussed, Prichard argued that the university had done nothing wrong.

The university's faculty association has complained of "unfair treatment" to Chun, who has received support from faculty members, students and others. The Ontario Human Rights Commission has appointed an investigator to look into the case.

Paul Gooch, the university's vice-provost for staff relations, says Chun did not win tenure-track competitions because better candidates were found. He says repeated offers of employment were made to Chun, including offers to place him elsewhere.

But Chun argues that those who won tenure were less qualified than he was, and that the university's offers would give him only the same status as his former assistants, of whom he had the largest team in geophysics in Canada. Chun adds that, unlike other university professors - and contrary to the rules of the principal federal grants bodies - he would still have to find his salary out of grants or contracts. He says that,

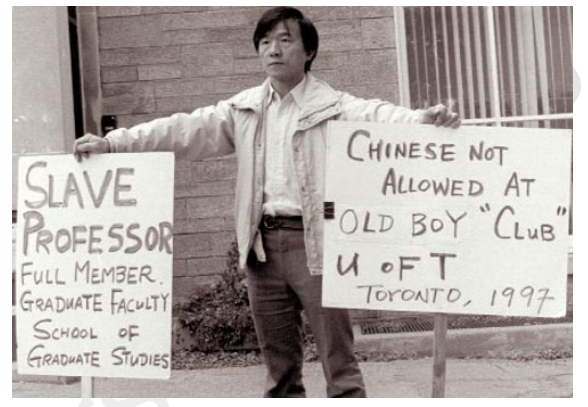

Chun: claims he had to carry out a professor's duties while working as a research associate.

although the university promised to try to find positions for him with other employers, they never came up with one.

Chun graduated from the University of Toronto with a bachelor's degree in engineering science, and won a master's from Columbia University in solid Earth physics and $\mathrm{PhD}$ from the University of California, Berkeley. After postdoc studies at Berkeley, he was attracted back to Toronto by an offer of a post as research associate. But on arrival he was told there were no funds to pay him.

Chun says that he was obliged to work as if he were a professor. He claims the university arranged for him to apply for external research funds, and that within six months he had attracted the largest grant in the history of the geophysics division.

The CAUT says Chun was apparently subject "to unfair procedures during at least two of the competitions for tenure-track positions in the physics department". The cancellation of a competition in 1987 in midstream to reappoint a previous faculty member without competition denied him fair consideration for the post, says the association. Yip's report suggested that this could have been done to keep Chun out of the job.

A Web site for Chun's support committee (http://www.utoronto.ca/acc/chun) says the university has never appointed a tenure or tenure-track geology or geophysics professor from a minority group. Three years ago, the CAUT claimed that "there are aspects of [Chun's] case which arouse a suspicion of [such] discrimination".

Derek Paul, physics professor emeritus at the university, wrote that, although the Yip report failed to uncover "overt racial bias", if it had probed more deeply it would probably have found "systemic" racial bias in the university hiring, and have refused to rule this out in Chun's case. "A lot of alumni are very concerned about the university, whose own investigation says it's exploited somebody," says Patrick O'Neill, chair of the CAUT committee.

DavidSpurgeon 